\title{
An overview of domestic aspects in US climate policy
}

\author{
Uma visão geral dos aspectos domésticos da política \\ climática dos EUA
}

SOLANGE REIS FERREIRA*

KELLY FERREIRA**

TULLO VIGEVANI***

Rev. Bras. Polít. Int. 55 (special edition): 88-103 [2012]

The article points out some of the domestic factors that contribute for understanding the United States position in international discussions on climate change. Firstly, it shows a recent and important judicial decision favorable to regulations. The outcome weakens a conservative strategy to delegitimize scientific findings and public policies. The second and third parts recall the discussion during the governments of Bill Clinton (1993-2001) and George W. Bush (2001-2009). The fourth section deals with the debate during Barack Obama's administration and identifies key actors, whether individuals or institutions, who allow or prevent progress in combating environmental regulations. The conclusion states that increasing conservatism in domestic political spectrum and anti-climate grassroots actions make improbable any advances on multilateral negotiations.

\section{Pre-electoral scenario in 2012}

The current debate in the US on climate change follows a political polarization increasingly common in the country. Most of the Democrats, except those who maintain a conservative view, seek to advance regulations to minimize global warming effects. Conversely, most Republicans go beyond the mere attempt to prevent the adoption of environmental laws. Leaders in the Republican Party build a detraction speech about scientific arguments that support the veracity of anthropogenic causes of global warming.

\footnotetext{
* PhD student at the University of Campinas (Unicamp), researcher at National Institute of Science and Technology for Studies on the United States (INCT-Ineu) and Coordinator of Observatório Político dos Estados Unidos (reissolange@gmail.com).

** Master in International Relations at Programa de Pós-Graduação em Relações Internacionais San Tiago Dantas and researcher at INCT-Ineu (kelly.ferreira@gmail.com).

*** Professor at São Paulo State University (UNESP), researcher at Centro de Estudo de Cultura Contemporânea (CEDEC) and at the INCT-Ineu (vigevani@unesp.br).
} 
The controversy is extended to legal arenas. An emblematic case is a recent decision of the US Court of Appeals for the District of Columbia. In June 2012, the judges issued a favorable opinion regarding the competence of the Environmental Protection Agency (EPA) to regulate greenhouse gases (GHG) emissions. The judicial action is due to a legal process presented by some industries and states to block the power of the agency.

According to the most comprehensive environmental legislation in the country, the Clean Air Act (CAA), EPA can regulate emissions if there is a direct risk to public health or the environment. However, none of its amendments considers the term "climate change" as a direct or even indirect threat. Based on such a legal gap, the detractors of climate legislation have always expected to impede related public policies. The impediment of nationwide regulations contributes to the continuing stagnation of US position in international negotiations.

The unanimous decision was announced by a panel of three judges: one conservative, appointed by Ronald Reagan, and two liberals, nominated by Bill Clinton. The Court found that EPA presented strong scientific proofs relating emissions of polluting gases, such as carbon dioxide, to global warming. The judges also found that higher temperatures on Earth negatively affect environment and therefore people's health. The opinion represents a victory for President Barack Obama, since the promise of improving climate laws was one of his political platforms in 2008. The following year, the House of Representatives passed an ambitious environmental legislation. However, the proposal was not considered in the Senate, where Senators were not able to vote anything similar. The Democrat defeat in 2010 elections sealed Obama's efforts.

The Court understanding must provide Obama with some power in case the current electoral contest against the Republican candidate Mitt Romney includes climate issues. Romney himself is pressured by radical right-wing groups in his own party to refute environmental protection measures. The main target of those climate opponents is certainly EPA, whose actions are commonly categorized as harmful to economy. This scenario not only impacts domestic policy in the United States, but it affects the strategy of the country in international forums as well.

\section{A borderless problem}

Although the article does not focus on international negotiations, it is useful to briefly overview the problem before proceeding in the analysis of domestic factors as determinants for the United States international climate policy.

The rising risks of climate change as a consequence of global warming have been mobilizing international community since events such as the manifesto The Limits of Growth by the Club of Rome in 1970 and the Stockholm Conference by the United Nations (UN) in 1972. Since the late 1980s, other meetings, programs 
and documents have been wakening awareness of public opinion and policymakers in many countries.

Among those events, it is possible to highlight the Brundtland Report in 1987, United Nations Environment Programme (UNEP), in 1988, and United Nations Conference on Environment in Rio de Janeiro four years later, in 1992. Most of the initiatives aimed to develop international regimes for environmental protection.

Since mid- $19^{\text {th }}$ century the temperature on Earth has been rising at a rapid pace. Scientific studies conducted by the Intergovernmental Panel on Climate Change (IPCC) indicate that this phenomenon is due to natural causes, but also to the industrial civilization, whose production mode depends on large-scale use of fossil fuels that generate greenhouse gas. Human activities cause most of carbon emissions, while thermal consequences of the consumption of fossil resources can be disastrous for life. As per International Energy Agency:

Continuing on today's path, without new policies, would mean rapidly increasing dependence on fossil fuels and continuing wasteful use of energy, taking us towards a concentration of greenhouse gases in the atmosphere in excess of 1,000 parts per million $(\mathrm{ppm})$ of $\mathrm{CO}_{2}$-equivalent. This [...] would almost certainly lead to massive climatic change and irreparable damage to the planet. ${ }^{1}$

Experts recommend the adoption of strict measures to avoid the increase in temperature over $2{ }^{\circ} \mathrm{C}$ above pre-industrial level in the current century. In 1990, global concentration of carbon dioxide in the atmosphere was already $354 \mathrm{ppm}$ against $280 \mathrm{ppm}$ in pre-industrial era. According to the scientific community, a level above $450 \mathrm{ppm}$ will probably cause unavoidable environmental disasters. In 2005 , the US was responsible for $20 \%$ of global emissions. ${ }^{2}$ However, the belief that economic development was directly linked to energy consumption delayed actions.

The last two administrations prior to Barack Obama - Bill Clinton and George W. Bush - were pressured by the international community to join agreements in multilateral forums. In 1992, the United Nations Framework Convention on Climate Change (UNFCCC) established the foundations of a broader discussion among governments and communities. Without proposing goals and targets, the treaty took the first step in creating a framework for international collaboration. The US was the fourth country to sign the agreement and the first among industrialized nations. ${ }^{3}$

1 International Energy Agency. World Energy Outlook. Paris: International Energy Agency.

2 Obama's New Climate Policy. Opportunities and Challenges of Climate Policy Change in the US. Stiftung Wissenschaft und Politik. SWP Research Papers, jul. 2010, p. 43.

3 PARKER, Larry B; BLODGETT, John E. UNITED STATES. Global Climate Change Policy: Evolving Views on Cost, Competitiveness, and Comprehensiveness. CRS Report for Congress. Order RL30024, p.1. 
As pollution does not respect borders, any solution requires a coordinated global action. However, its execution implicates technological, economical and political costs. Therefore, perceptions over those implications by domestic sectors prevented the US from an effective international cooperation. What seemed to be an upward path on climate action at the beginning of the Clinton administration, for example, became an insurmountable challenge during his government and the following one.

As Daniel Yergin states, a new environmental agenda "will hardly come to pass without major battles of accuracy of the science and its prediction, the extent of the risks, the proper remedies and the costs." " The perception of the environment as a social good, with extra costs for government and productive sectors, prevents a broader cooperation among politicians.

Nevertheless, the development of effective global action requires US participation, as well as awareness from its leaders about the urgency of establishing a new paradigm of energy consumption. To understand its role in international negotiations on climate change and global warming, it is necessary to observe domestic politics and its various interests and values.

\section{US climate policy in Clinton and Bush administrations}

Bill Clinton's climate policy can be split into two phases: before and after the mid-term elections of his first administration. Elected in 1992, Clinton counted on a Congress controlled by the Democratic Party in the first two years. That advantage would be lost before the end of the first term, when Republicans won the general elections in 1994. The consequence was the recovery, unprecedented since 1950, of the majority of seats in Congress by the Republican Party.

Initially, the President announced plans to tax energy consumption and to create a program in accordance with the UNFCCC. Both projects were rejected by Congress while Democrats still controlled it. In 1993, the government presented the Climate Change Action Plan (CCAP), which comprised administrative initiatives to reduce GHG emissions in 2000 by 1990 levels. Although its implementation was due to federal government, Congress had an important control over CCAP since federal agencies relied on US\$ 1.9 billion to be released by Congress. After mid-term elections, appropriations became a daily battle between Executive and Legislative.

As distribution of legislative seats favored Republicans, the party leadership adopted a negative posture towards most federal proposals. In fact, Republicans proposed its own agenda known as "Contract with America." The Republican strategy, which advocated for a minor government intervention on economy, saw

4 YERGIN, Daniel. The prize: the Epic Quest for Oil, Money \& Power. New York: Free Press, 1992, p. 785.

5 The Contract with America: Implementing New Ideas in UNITED STATES. The Heritage Foundation, Oct. 12, 1995. 
CCAP as state interference in market. In 1997, when emissions were around 13\% above 1990 level, Clinton attributed the failure of his energy plan to a financial embargo by the rival party over nearly 50 programs in CCAP. ${ }^{6}$

Aspects of domestic politics reflected significantly in US behavior during international negotiations. American delegates questioned the goals proposed by European Union (EU) and pushed for greater responsibility from developing countries. ${ }^{7}$ Other concern was to make Europeans and Japanese agreeing to similar parameters in order to avoid that climate change "externalities" jeopardized competitiveness. According to Rafe Pomerance, former deputy assistant secretary of State for Environment and Development, the main objective in the Conference of Parties (COP-1), in Berlin, 1995, was to avoid EU imposing emission targets. ${ }^{8}$

International delegates agreed that developing countries should participate on voluntary basis, without commitment to pre-established targets. Nowadays, this flexibility is still one of the causes for resistance by Congress in engaging the country in a global climate regime.

Despite the difficulty in coordinating external and internal requirements, the Clinton administration has never abandoned negotiations, as George W. Bush would do later. During COP-2, held in Geneva in the following year, undersecretary for Global Affairs, Timothy Wirth, said that the country would consider accepting a legal bind if reduction goals were realistic. The US would not accept dealing with idealized figures unrelated to economic reality. Moreover, solutions adopted should be market-oriented, which meant not only preserving profit margins for industries, but turning global-warming fight into business. Ecological economics have been on environmental agenda since the 1960s, but never succeeded in the US and certainly did not produce the results that were expected in the 1980s. ${ }^{9}$ Finally, the agreement should be flexible enough to incorporate an increasing number of countries.

Prior to COP-3, in Kyoto, 1997, the importance of the treaty was to be stressed for public opinion and decision makers. Therefore, a task force was created under Todd Stern's leadership, who would become Obama's special envoy for later international negotiations. The group comprised officials from several federal agencies, whose assignment was, among other things, to clarify issues for environmental groups, industrial sectors, politicians and public opinion.

Clinton himself spoke at National Geographic Society on October 22, 1997. He referred to the climate issue as a global problem of particular concern

\footnotetext{
6 PARKER, Larry B; BLODGETT, John E. UNITED STATES. Global Climate Change Policy: Evolving Views on Cost, Competitiveness, and Comprehensiveness. CRS Report for Congress. Order RL30024, p. 11.

7 ROYDEN, Amy. UNITED STATES. Climate Change Policy Under President Clinton: A Look Back. Golden Gate University Law Review. Volume 32, Issue 4. Rio’s Decade: Reassessing the 1992 Earth Summit, Sept. 28, 2010, p. 8.

8 Idem.

9 PEARCE, David. Greening in the World Economy. London: Earthscan Publications, 1991.
} 
in industrialized and developing countries. The President declared that, despite the uncertainty about the extent of the phenomenon, scientific findings were solid enough to bring the subject to public and political spheres. Clinton's goal was to legitimize the issue. Besides that, bilateral dialogues were initiated with countries like Australia, Japan, Canada and Russia.

Meanwhile, profound differences emerged in relation to traditional partners in the old continent. EU proposed to reduce 15\% of emissions in 2000 over 1990 levels. For Washington the focus should be stabilizing rather than reducing emissions. The nation also disagreed with other criteria: establishing the same percentage for the entire block and leaving the responsibility of determining individual limits to the European Commission. American delegates understood that this would allow Europeans to create their own trading system for emission quotas.

The efforts to obtain cooperation from domestic political class were useless. By 95 votes in favor and none against, Senate approved a bipartisan resolution named Byrd-Hagel (S.Res.98), ${ }^{10}$ introduced by Robert Byrd (D-WV) and Chuck Hagel (R-NE). The resolution discouraged the signature of the treaty based on the perception that the instrument would impose limits to American economy and favor developing countries. Besides having fears of interfering in free market, politicians were highly influenced by the oil lobby.

In order to reduce international pressure, government moved forward internally. Among other federal programs, it established the Climate Change Technology Initiative (CCTI), which provided US\$ 6.3 billion in investments and tax incentives to increase energy efficiency in the country.

Congress tried to block it by rejecting funds for its implementation. The greatest criticism, however, was oriented towards EPA, which Congress rightly believed would be a federal instrument to regulate carbon emissions. Environmental policy in the US can be implemented at national level through legislation passed by Congress or by EPA regulation. The agency, however, could only rule in cases related to human health, since climate change and global warming were not comprised in any national legislation. Anti-EPA politicians also try to question the agency's legal authority.

In 1970, Congress passed the CAA as the first instrument against emissions in US history. Previous laws, such as the Air Pollution Control Act of 1955, the Clean Air Act of 1963 and the Air Quality Act of 1967 dealt with research and development, and pollution control, but only CAA covered the emissions control. In the same year, former President Richard Nixon created EPA to consolidate into one agency a variety of activities under the CAA. After being amended in 1990, CAA expanded its scope to adopt measures related to individual health and the environment. It is primarily based on this amendment that EPA has been able to bypass many barriers.

10 PARKER, Larry B; BLODGETT, John E. UNITED STATES. Global Climate Change Policy: Evolving Views on Cost, Competitiveness, and Comprehensiveness. CRS Report for Congress. OrderRL30024, p. 12. 
The Clean Air Act (...) defines the Environmental Protection Agency's responsibilities for protecting and improving the nation's air quality when a substance has been determined to endanger human health and the environment. (Light, Weiss, Kaufman, James 2010, 4)

When COP-3 (Kyoto) took place, Todd Stern proposed a global policy based on the following principles: to be guided by science, to be lined with market, to promote new technologies without causing the destruction of old ones, to promote global participation, and to monitor scientific and economic reviews.

After the conference, Bill Clinton signed the Kyoto Protocol, which was harshly criticized at home. "In signing the Kyoto Protocol, the President blatantly contradicts the will of the US Senate" (Chuck Hagel) ${ }^{11}$ But the treaty was never submitted to Senate for ratification. After signing it, the President faced the most serious crisis in his government. After admitted involvement in a sex scandal in the White House, Clinton was threatened by the shadow of impeachment in the following months. Given this scenario and the Byrd-Hagel Resolution, the chance for ratification had become void.

Despite the setback, Clinton said - in the State of the Union speech in January 1999 - that global warming represented the greatest challenge to the country. In the following month, the government included US\$ 4.1 billion for climate programs in the budget proposal for fiscal year 2000,34\% more than in previous year.

As a reaction, Senators introduced a bipartisan initiative named Climate and Energy Policy Act of 1999. Although it did not pass, the act differed from the Kyoto Protocol in several respects. Above all, the proposal rejected the signature of the Treaty based on noncompliance by developing countries and mandatory provisions for developed ones.

The Clinton administration succeeded in opening a national dialogue, yet this was marked by advances and setbacks. In international negotiations, the question involved the role of developing countries, targets reductions over 1990 level, and a mandatory legal instrument.

The different position between the US and EU became clear during COP-6, in The Hague, in 2000. Europeans argued that by regulating emissions in industrialized countries, a climate regime could take to a lesser consumption of fossil resources. Climate change strategy based only on free market would not produce the effects needed to prevent the increase in global warming.

Washington defended other measures such as the inclusion of agricultural lands and forests as mitigating factors. As these environments are considered as potential loci for carbon sequestration, countries with agriculture and forestry vocation would benefit from this methodology. Considering favorable geographical

11 United States signs a pact to reduce gases tied to warming. The New York Times, Nov. 13, 1998 
characteristics of the US, it was believed that such a determination would allow the country to avoid larger quotas and restrictions.

The country also supported the creation of quotas trading system. Thus, the most polluting nations would buy surplus emissions quotas from countries that pollute less. Such proposals indicated a willingness to contribute for combating global warming without promoting structural changes in its own pattern of consumption and production.

In January 2001, IPCC concluded that "new and stronger evidences proved that global warming over the last 50 years is attributable to human activities."12 Two months later, the newly-elected President George W. Bush announced the US would abandon Kyoto negotiations. The decision was taken in alignment with Byrd-Hagel Resolution. Before the formal abandonment, Bush sent a letter to Republican Senators Chuck Hagel (R-NE), Jesse Helms (R-NC), Larry Craig (R-ID) and Pat Roberts (R-KS), which would symbolize the country position in global forums during his administration.

As you know, I oppose the Kyoto Protocol because it exempts $80 \%$ of the world, including major population centers, such as China and India, from compliance, and would cause serious harm to the US economy. [...] At a time when California has already experienced energy shortages, and other Western states are worried about price and availability of energy this summer, we must be very careful not to take actions that could harm consumers. This is especially true given the incomplete state of scientific knowledge of the causes of, and solutions to, global climate change and the lack of commercially available technologies for removing and storing carbon dioxide. (Bush 2001) ${ }^{13}$

To reduce the impact of his statements on the scientific community and environmentalists, Bush requested a study on probable causes of climate change to the National Academy of Sciences (NAS). The result was not the one expected by the administration since the report endorsed IPCC. ${ }^{14}$ Thereafter, the President announced his intention to create the Climate Change Research Initiative in order to study uncertain areas and determine investments.

In addition, private sector initiatives sought similar evidences. The association Global Climate Coalition, formed by large petrochemicals, oil and automobiles corporations, led an aggressive campaign to respond to IPCC and strengthen the perception that climate change was a scientific creation. The group was eventually

12 Climate Change 2001: Synthesis Report. Summary for Policymakers. An Assessment of the Intergovernmental Panel on Climate Change.

13 Letter from the President George W. Bush to Senators Hagel, Helms, Craig, and Roberts. IOS Press, March 13, 2011. See at <http://iospress.metapress.com/content/c87cge4kd7mcjbu4/fulltext.pdf>. Aug. 13, 2012

14 ROSENCRANZ, Armim. UNITED STATES. Climate Change Policy under G. W. Bush. Golden Gate University Law Review. Volume 32. Issue 4 Rio’s Decade: Reassessing the 1992 Earth Summit, Sept. 28, 2010. 
dissolved in 2002 after its own experts confirmed that human action on global warming was an undeniable idea. ${ }^{15}$

Just before giving up on Kyoto, the White House created the National Energy Policy Development Group (NEPDG). Under the leadership of Vice President Dick Cheney, the group was intended to address challenges such as energy blackouts in California, the increase in energy prices, the reduction in domestic production of natural gas and the dependence on foreign oil. The fundamental question for the new administration was not climate, but energy. After 2005, the NEPDG would work to make the country less dependent on foreign oil by encouraging domestic exploration of oil and gas, especially on offshore zones and natural reserves. Cheney proposed to move forward on federal lands, including the Arctic National Wildlife Refuge in Alaska, a clear setback for climate change.

Bush tried to dismantle some programs created by Clinton, as the Partnership for a New Generation of Vehicles, which aimed to produce cars with efficiency for 80 miles per gallon. Instead of increasing the efficiency of domestic cars, the new government chose to invest in vehicles powered by hydrogen, a technology not yet available for large-scale application.

In the State of the Union address of 2002, the President announced plans to offer tax credits for renewable energy, hybrid and hydrogen cars, as well as technologies to reduce $\mathrm{CO}_{2}$ emissions. ${ }^{16}$ However, Bush was opposed to regulate GHG emissions. The reductions should be achieved through voluntary actions by private sector without government interference. As an alternative to Kyoto, Bush suggested the creation of the Climate Change Initiative in 2002, also aiming to reduce not the emission, but the intensity of greenhouse gas by $18 \%$ in 2012 .

In subsequent years, the government tried to engage in bilateral or regional negotiations and not in multilateral discussions. ${ }^{17}$ That was the case of Asian-Pacific Partnership on Clean Development and Climate (2006), that established bilateral partnership with Australia, Canada, China, South Korea, India and Japan to solve problems of energy security, climate change and air pollution.

As someone linked to fossil industries, Bush maintained a certain consistency defending oil sector. Under his administration, government proclaimed the belief in free market as a panacea for any economic illness and that emission control by an international regime would result in market inefficiency.

15 Industry Ignored Its Scientists on Climate. The New York Times, Apr. 23, 2009.

16 ROSENCRANZ, Armin. UNITED STATES. Climate Change Policy under George W. Bush. Golden Gate University Law Review, Volume 32, Issue 4 Rio's Decade: Reassessing the 1992 Earth Summit, Article 4, Sept. 28, 2010, p. 11.

17 Obama's New Climate Policy. Opportunities and Challenges of Climate Policy Change in the US. Stiftung Wissenschaft und Politik. SWP Research Papers, jul. 2010, p. 7. 


\section{US climate policy in Obama administration}

On the other hand, Barack Obama has planned part of his 2008 presidential campaign on promises of change over sensitive issues for American society, used to high standards of energy consumption. Obama said it would seek to reduce dependence on oil and confront climate change, tackling emissions of carbon dioxide and other greenhouse gases. The main goals were to reduce emissions by $80 \%$ by 2050 , increase the share of renewable energy to $25 \%$ of total consumption, and create a carbon-trading system. ${ }^{18}$

The campaign has brought some fresh air to environmental debate. Thus, the Obama-Biden Platform devised a work plan which aimed to foster US leadership in the so-called "green revolution." The Democratic candidate saw the 2008 financial crisis as an opportunity to link economic recovery and transformation of energy paradigm in the same stimulus package.

The Green Economic Recovery Program, elaborated by the Center for American Progress and Political Economy Research Institute at the University of Massachusetts, suggested short- and long-term measures to mitigate crisis effects, and medium and long term to reform the economy and implement environmental policies. Thus, the economic recovery and the adoption of energy and environmental policies would be interdependent.

This strategy, announced in the New Energy for America plan, tried to attract voters with a promise of quick relief on increasing energy price, to reduce carbon emissions to $80 \%$ below 1990 levels, and to reduce dependence on foreign oil. Medium- and long-term measures aimed to promote a reform in the energy matrix focused on clean energy.

In order to create five million jobs, US\$ 150 billion would be invested in the following ten years to foster automotive companies to produce and sell hybrid cars. Seeking to align business and labor interests, training centers would be created for the development of skilled workforce. Obama expected to put one million hybrid vehicles on the streets by 2012 .

Other projects included smart grids in association with solar panels, and the development of energy efficiency. Similarly, loan guarantees programs for alternative energy have been offered by the Department of Energy as part of the American Recovery and Reinvestment Act of 2009.

However, the biggest challenge concerned cap-and-trade, which proposes limits on emissions and revenue through trade quotas. About US\$ 15 billion annually collected from cap-and-trade would be invested in clean energy, efficiency and new fuel generation.

Obama became President with the support of the progressive base in his own party and minorities of the population, such as the youth. He was also welcomed by people and institutions involved in combating global warming. Greenpeace in

18 Idem, p. 5. 
the US said that Obama's historic inauguration opened a time of great potential. As per German think tank Stiftung Wissenschaft und Politik, "the new administration is distinguished by the notorious climate policy ambitions." 19

Those expectations were soon frustrated. Like Bush, the new President took some initiatives in reduced forums such as the US-China Memorandum of Understanding to Enhance Cooperation on Climate Change, Energy and the Environment (2009). ${ }^{20}$ Obama attended COP-15 in Copenhagen in 2009, but was not able to advance the agreements. The US pledged to reduce carbon emissions by $17 \%$ over 2005 levels by 2020 , and to reach $83 \%$ in 2050 .

COP-15 ended with an unexpected result: a group of countries that included China, US, India, Brazil and South Africa submitted a side proposal. The plan, which was not accepted by other participants, meant a victory for Washington since it led to an informal commitment by some major developing countries. ${ }^{21}$ However, the conference ended without resolving a core issue: finding a substitutive instrument for the Kyoto Protocol up to 2012.

Held in Cancun in the following year, COP-16 achieved modest but important gains. One regards the recovery of UN credibility in leading multilateral efforts. Also notable was an accord among rich and poor countries, which established two formal mechanisms: the Green Climate Fund, to transfer US\$ 100 billion a year from advanced economies to environmental projects in less-developed nations, and the agreement on Reducing Emissions from Deforestation and Forest Degradation (REDD+), which compensates countries that preserve tropical forests.

The outcome of COP-17, in Durban 2011, was also positive for Washington. Developing countries, such as China and India, agreed to elaborate a plan to limit their GHG emissions. The terms of Durban Platform for Enhanced Action will be discussed between 2012 and 2015, although it will only be effective in 2020 . The conference also resulted in the renewal of the Kyoto Protocol for a period between 5 and 8 years, and progress towards the creation of the Green Climate Fund. Analysts, however, consider such results as poor since the two biggest world polluters - China and the US - continue to be absent from the international treaties.

For Professor of History and Social Policy in Harvard, Alexander Keyssar, Obama won the election mainly because he is not George W. Bush and introduced a transformative agenda. However, structural constraints as well as personal characteristics led him to compromise everyday with his opponents, disappointing his own base. ${ }^{22}$ Economic crisis, high unemployment rate and huge budget deficit hampered Obama's chances in addressing the climate question.

19 Idem, p. 6.

20 US-China Memorandum of Understanding to Enhance Cooperation on Climate Change, Energy and the Environment. U.S. Department of State. Press Statement. July 28, 2009. See <http://www.state.gov/r/pa/prs/ ps/2009/july/126592.htm>. Aug. 13, 2013.

21 Q\&A: The Copenhagen climate summit. BBC News. Dec. 21, 2009.

22 KEYSSAR, Alex. The Balancing Act of Barack Obama. Observatório Político dos Estados Unidos. 
Despite those difficulties, the Democratic Party has taken some positive initiatives. In May 2009, Henry Waxman (D-CA) and Edward Markey (D-MA) introduced a proposal in the Committee on Energy and Commerce that would be later approved in the House of Representatives as the American Clean Energy and Security Act of 2009. It was one of the most ambitious proposals already presented due to its cap-and-trade provisions.

The overall goals in Waxman-Markey bill were to reduce GHG emissions in $17 \%$ by 2020 over the 2005 level (and $83 \%$ by 2050); to create jobs related to renewable energy production; to achieve energy independence; to reduce pollution; to promote transition to an economy based on renewable energy; to develop proper ecological transportation; to encourage clean energy credit programs; and to export technology for the development of renewable energy. The text also highlighted EPA competence to regulate GHG emissions and carbon credits trade.

The initiative received support from 61 groups of interest, including Sierra Club, Union of Concerned Scientists, One Sky, Clean Water Action, American Rivers and the Environmental Defense Fund. Its critics comprised, among others, Greenpeace, American Farm Bureau Federation, Friends of the Earth, Rainforest Action Network, Public Citizen, and Murray Energy Corporation.

It is noteworthy that the eclectic composition of the second group includes environmentalists, fossil industries and associations of consumers and taxpayers. Greenpeace, for example, ${ }^{23}$ believed that the proposal would benefit capitalist interests at the expense of environment by allowing the purchase of carbon credits by the most polluting industries. Members of oil industry criticized the law precisely because it would oblige them to acquire government permissions to offset carbon emissions, leading to increase in production costs. Finally, taxpayers feared rising of energy prices.

On June 26, 2009, Waxman-Markey bill was finally passed in the House of Representatives with a tight margin of 219 votes (including eight Republicans) against 212 . Although the resistance to climate policies is usually attributed to Republicans, the Democratic majority did not vote consensually.

But the proposal had a short life in Congress since Senate chose to discuss its own projects, such as the Clean Energy Jobs and American Power Act (S.1733), introduced by Senators John Kerry (D-MA) and Barbara Boxer (D-CA). Despite suggesting a $20 \%$ reduction on 2005 emissions, the initiative was considered as more lenient than Waxman-Markey because it made greater concessions to industries. But the majority leader, Harry Reid (D-NE), chose not to include Kerry-Boxer bill in the agenda.

Kerry rehearsed a new tripartite project with Joseph Lieberman (I-CT) and Lindsey Graham (R-SC) to reduce by 17\% the GHG emissions in 2020 over 2005

23 Greenpeace opposes Waxman-Markey: Climate Bill not Science-Based; Benefits Polluters. Greenpeace. See at $<$ http://www.greenpeace.org/usa/en/media-center/news-releases/greenpeace-opposes-waxman-mark/>. Aug. 13, 2012. 
rates, and $83 \%$ by 2050 . This second attempt did not receive support from the majority leader, who preferred to undertake efforts in matters of immigration, a topic that would be most crucial for his reelection in 2010. ${ }^{24}$ The campaign by right-wing groups, like Tea Party and Fox News, also led conservative Graham, one of its authors, to abandon the initiative. ${ }^{25}$

Since then, many Republicans emphasized their skepticism about the veracity of climate change as a result of global warming. The power of this argument among conservatives has been such that a pre-candidate in Republican primary in 2011/2012, Newt Gingrich, sought to delink his image from his own past statements.

I had a dialogue with Senator John Kerry recently and I started by saying let's stipulate that it is [a] problem that global warming is going on, that it is conceivable that humans have a role and therefore as a matter of prudence we ought to have less carbon loading of the atmosphere. (Gingrich 2007) ${ }^{26}$

Social sectors wonder at what moment the Republican Party so firmly embraced this denial.

That's deeply troubling. It's one thing when people disagree on the effectiveness of different approaches to fix a problem; it's worse when they refuse even to believe that a problem exists - despite an overwhelming scientific consensus that says it does. One of America's major political parties has, in effect, adopted denial as policy. How did we get here? ${ }^{27}$

Besides, the resistance against any sort of state intervention in the economy and the connection with traditional energy sectors characterize most conservative Congress members. Republicans and moderate Democrats do not believe either that clean industry generates a significant number of jobs.

Compared to its predecessor, it can be said that Obama has taken over the issue in a positive way. The President and his advisers on matters of energy and climate officially declare their acceptance of scientific findings and are keen to discuss the matter. Between rhetoric and practice, however, there is a polarized Congress, the largest fiscal deficit in the history of the country and the largest economy in the world to reheat.

The Obama administration believes that the adoption of a clean energy model would not only solve climate change, but also economic problems arising from the loss of competitiveness in recent years. Taking the lead in innovation

24 Sen. Reid to push climate bill before immigration. Reuters, April 28, 2010.

25 Graham completes break with Kerry climate plan, backs Lugar energy bill with no emissions cap. The Hill, June 9, 2010.

26 Gingrich on Climate - The 2007 Version.

27 Who's Bankrolling the Climate-Change Deniers? Time, Oct. 4, 2011. 
and green technology can be a key factor for the US to maintain its economic and political supremacy.

\section{Conclusion}

In discussions on green economy, a strong criticism that arises in relation to neoclassical theory is that its conception of production mode does not take into account that natural resources are finite. Albeit in a cautiously way, it is possible that Obama's team tries to incorporate the absorption of elements of green economy in a liberal perspective.

The US role in international negotiations on global warming is profoundly determined by domestic political factors. The greatest difficulty is to overcome the resistance of political and economic groups, who see the idea of an international regime to combat climate change as a threat to economy.

Besides, limits on carbon emissions and energy efficiency standards are seen as state interference in the largest economy in the world market. As clean energy industries still demand government incentives in its initial phase, the change of paradigm faces a strong resistance among the political class.

Moreover, the country's political system allows groups of interest to influence Congress. Given the seniority of fossil lobbies and the connection of many Congress members with some states and districts that produce traditional energy, the enactment of climate laws becomes turbulent and difficult. Another obstacle to be overcome is the disbelief in scientific conclusions, including those developed by the IPPC.

More recently, the climate change issue has been considered as a variable in the competition among countries and regions. EU uses environmental issue as an important instrument to strengthen its soft power. Brazil has gained greater respectability, as well as responsibility. China intervenes in the debate, presenting itself as a country that fosters its green industry.

The policies experimented by Bill Clinton and Barack Obama, though shy, showed some progress in these directions. That clearly indicates greater affinity with the theme among Democrats. However, the rise of radical political forces became a challenge for Obama's reelection. Moreover, the emergence of these forces complicates multilateral agreements on climate change. The US position risks its international prestige, which ends up impacting the interests of the country in the world.

\section{Bibliographic references}

Climate Change 2001: Synthesis Report. Summary for Policymakers. An Assessment of the Intergovernmental Panel on Climate Change.

Gingrich on Climate - The 2007 Version. 
Greenpeace opposes Waxman-Markey: Climate Bill not Science-Based; Benefits Polluters. Greenpeace. See <http://www.greenpeace.org/usa/en/media-center/news-releases/greenpeaceopposes-waxman-mark/>. Aug. 13, 2012.

Industry Ignored Its Scientists on Climate'. The New York Times, Apr. 23, 2009.

International Energy Agency. World Energy Outlook. Paris: International Energy Agency.

Letter from the President George W. Bush to Senators Hagel, Helms, Craig, and Roberts. IOS Press, March 13, 2011. See in: http://iospress.metapress.com/content/c87cge4kd7mcjbu4/ fulltext.pdf. Aug. 13, 2012.

KEYSSAR, Alex. The Balancing Act of Barack Obama. Observatório Político dos Estados Unidos (OPEU). Estudos e Análises de Conjuntura, no. 3, 2011.

Obama's New Climate Policy. Opportunities and Challenges of Climate Policy Change in the US. Stiftung Wissenschaft und Politik. SWP Research Papers, jul. 2010.

PARKER, Larry B; BLODGETT, John E. UNITED STATES. Global Climate Change Policy: Evolving Views on Cost, Competitiveness, and Comprehensiveness. CRS Report for Congress. Order RL30024.

PEARCE, David. Greening in the World Economy. London: Earthscan Publications, 1991.

Q\&A: The Copenhagen climate summit. BBC News. Dec. 21, 2009.

ROSENCRANZ, Armim. UNITED STATES. Climate Change Policy under G.W.Bush. Golden Gate University Law Review. Volume 32. Issue 4 Rio's Decade: Reassessing the 1992 Earth Summit, Sept. 28, 2010.

ROYDEN, Amy. UNITED STATES. Climate Change Policy Under President Clinton: A Look Back. Golden Gate University Law Review. Volume 32, Issue 4 Rio's Decade: Reassessing the 1992 Earth Summit, Sept. 28, 2010.

Sen. Reid to push climate bill before immigration. Reuters, Apr. 28, 2010. Graham completes break with Kerry climate plan, backs Lugar energy bill with no emissions cap. The Hill, June 9, 2010.

The Contract with America: Implementing New Ideas in UNITED STATES. The Heritage Foundation, Oct. 12, 1995.

U.S.-China Memorandum of Understanding to Enhance Cooperation on Climate Change, Energy and the Environment. U.S. Department of State. Press Statement, July 28, 2009. See <http:/www.state.gov/r/pa/prs/ps/2009/july/126592.htm>. Aug. 13. 2012

United States signs a pact to reduce gases tied to warming. The New York Times, Nov. 13, 1998.

Who’s Bankrolling the Climate-Change Deniers? Time, Oct. 4, 2011.

YERGIN, Daniel. The prize: the Epic Quest for Oil, Money \& Power. New York: Free Press, 1992.

Received August 13, 2012

Accepted September 15, 2012 


\begin{abstract}
The article shows how domestic aspects influence the United States national and international climate policy. To accomplish the task, the authors analyzes the discussions when Bill Clinton was ruling the country, a time during which global discussions were forwarded. The paper recalls the debate in the Bush administration and the growing polarization since Barack Obama took office.
\end{abstract}

Keywords: climate policy; domestic interests; United States.

\title{
Resumo
}

Este artigo mostra como os aspectos domésticos influenciam as políticas climáticas nacional e internacional dos Estados Unidos. Para cumprir essa tarefa, os autores analisam os debates que ocorreram durante o período em que Bill Clinton governava o país, quando os debates globais foram encaminhados. Este trabalho relembra o debate durante o governo Bush e a crescente polarização desde a ascensão de Barack Obama ao poder.

Palavras-chave: política climática; interesses domésticos; Estados Unidos. 